\title{
Business Groups and Corporate Responsibility for the Public Good
}

\author{
Melsa Ararat $^{1} \cdot$ Asli M. Colpan ${ }^{2} \cdot$ Dirk Matten ${ }^{3}$ \\ Received: 2 May 2018 / Accepted: 8 May 2018 / Published online: 7 June 2018 \\ (c) Springer Science+Business Media B.V., part of Springer Nature 2018
}

\begin{abstract}
This paper analyzes the relationship between Business Groups as a distinct way of organizing economic activities and their relation to the public good. We first analyze the phenomenon of Business Groups and discuss some of their core features. Subsequently, the paper moves to analyzing the existing literature on Business Groups and corporate social responsibility (CSR) as the most common label for the topic of this Special Issue. Subsequently, specific peculiarities of Business Groups in the context of CSR and their contribution to the public good are fleshed out. Based on this analysis, the paper delineates some implications for the field of CSR and the wider debate on the nature of the firm. We close with some perspectives for future research.
\end{abstract}

Keywords Business groups · Corporate social responsibility $\cdot$ Corporate governance

\section{Introduction}

Business Groups have garnered growing attention of management scholars over the past decade (Colpan et al. 2010). Business Groups can broadly be described as "an economic coordination mechanism in which legally independent companies, bound together with formal and informal ties, utilize collaborative arrangements to enhance their collective economic welfare" (Colpan and Hikino 2010, p. 17). Mainstream management and specifically the international business literature appear however to treat the phenomenon of Business Groups (BGs) as an epiphenomenon, rather than a core subject worthy of scholarly relevance.

Dirk Matten

dmatten@schulich.yorku.ca

Melsa Ararat

melsaararat@sabanciuniv.edu

Asli M. Colpan

colpan@gsm.kyoto-u.ac.jp

1 School of Management, Sabancı University, Orhanli, Tuzla, 34956 Istanbul, Turkey

2 Graduate School of Management and Graduate School of Economics, Kyoto University, Yoshida-Honmachi, Sakyo-ku, Kyoto 606-8501, Japan

3 Schulich School of Business, York University, 4700 Keele Street, Toronto M3J 1P3, Canada
Given the significance of and recent growth of BGs such a view appears rather surprising. In many emerging economies such as Brazil, Korea, Indonesia, or Turkey, BG firms represent more than half of listed firms and also represent more than $50 \%$ of the total market cap (Khanna and Yafeh 2007). 45 of India's largest 50 enterprises and 28 of the largest 50 enterprises in Turkey are BGs; in Korea, more than $80 \%$ of GDP is generated by BGs (Holmes Jr et al., 2016; Colpan 2010). The significance of BGs is not only limited to emerging economies; in Western Europe, some BGs, such as the Wallenberg group in Sweden, the Agnelli group in Italy, or the Mondragon group in Spain, have significant influence. In North America, Koch Industries in the US and the Weston group in Canada are amongst the most influential players in their respective industries (Colpan and Hikino 2018).

One reason why the significance of BGs is neglected, as Williamson (1991) argued, is that conceptually they often straddle the sphere between markets and hierarchies. The phenomenon of BGs remains multifaceted (Colpan and Hikino 2010, 2018). BGs are a set of legally independent firms, operating in multiple and often unrelated industries, whose economic activity is controlled and coordinated via equity stakes, privileged control rights, interlocking directorates, informal ties, and others (Khanna and Yafeh 2007; Ararat et al. 2017).

Until recently, economists assumed that diversified BGs could only exist in the absence of well-functioning markets as functional substitutes for efficient external markets and 
strong institutions (Leff 1978). This assumption is challenged by the prevalence of BGs not only in less developed but also in mature economies (Jones 2015; Colpan and Hikino 2018). A particular area of interest in BGs in the management literature appears to be, their at times, considerable engagement in practices under labels such as corporate (social) responsibility, corporate sustainability, corporate citizenship and similar terms which are used synonymously here, under the umbrella term 'corporate social responsibility' (CSR; see Matten and Moon 2008).

BGs, particularly in emerging economies, contribute remarkable levels of financial, organizational, and technological investment in the wider public good of those communities, countries, and regions in which they operate. Examples are numerous and include family governed BGs in India and Turkey, some of the Korean Chaebols, Japanese Keiretsu, and large BGs in Latin America and Europe. It appears that BGs are particularly well situated to address social needs such as poverty, governance deficits, and institutional voids in welfare state provision and public governance.

The social roles assumed by BGs transcend the understanding of CSR from the traditional theory of the firm perspective. This understanding views corporate responsibility for the public good as voluntary policy choices and activities, which are expected ultimately to contribute to the bottom line (McWilliams and Siegel 2001). Examining the engagement of BGs for the public good, especially in developing/emerging contexts, reveals a much broader and richer picture that includes, but goes significantly beyond the scope of standard CSR practices. BGs, often through charitable foundations as well as their operating firms, address institutional voids. They provide education and employment in areas where they are most needed, products, and services that effectively substitute and emulate what would be considered welfare state provisions in liberal, developed democracies. BGs are also pivotal to the functioning of markets, the organization of the economy, and the basic building blocks of the political economy.

This societal role and the efficiency benefits of BGs remain, however, controversial: BGs are often seen as being heavily involved in political rent-seeking (Krueger 1974; Schneider 2010), investing primarily in political connections, as opposed to productive assets. Baumol (1990) argues that large, invasive, and corrupt governments can make political rent-seeking the highest return on investment, and that this can stall economic development. This may include promoting a status quo in which particular rentseeking BGs do well, as do the politicians that favor them. The BGs' investments in government connections yield high returns in subsidies, trade protection, tax breaks, and protective barriers to entry, but the economy suffers from a lack of genuine investment in productivity-improving assets and thus stagnates (Morck et al. 2005). This is often referred to as an "economic entrenchment trap"; this phenomenon describes predominantly the strategic positioning of many BGs in emerging economies.

Other concerns regarding the responsibilities of BGs revolve around the corporate governance processes that have often been the subject of controversy. The finance literature emphasizes conflicts of interest between controlling shareholders and minority investors, where pyramidal structures, built by controlling shareholders through a chain of equity ties, provide ample opportunities for direct (La Porta et al. 1999; Almeida and Wolfenzon 2006) or indirect tunneling (Bebchuk and Hamdani 2018). A major concern is that controlling shareholders in these organizations-often powerful families-may use various instruments to exercise control over the entire business, thereby effectively disempowering and expropriating minority shareholders in affiliated firms, to maximize their own wealth. (Almeida and Wolfenzon 2006; Djankov et al. 2008).

The perceived or actual knock-on effects of controversial corporate governance practices can have disastrous impact on the depth and efficiency (often the mere existence) of capital markets in those countries affected. It may also impair a country's ability to attract equity investments. The possibility of expropriation furthermore encourages various forms of corruption, as evidenced by the scandal around the Italian BG Parmalat (Melis 2005) in the early 2000s. From this perspective, the question of whether BGs are "paragons and parasites" (Khanna and Yafeh 2007) is open to debate considering the structural effect of the collective dominance of BGs on the economy. Although this line of inquiry largely focuses on the BGs in emerging and developing economies, developed economies have also been under the spotlight (Belenzon et al. 2013; Carney et al. 2011).

Despite the growing attention BGs have received in recent years in scholarly debates, most studies have focused on why they exist and, contrary to the expectations of a few decades ago, why they are persistent. BGs' impact, roles, and their assumption of social responsibilities for the wider public good have only received scant and, at best, anecdotal attention in literature. As an illustration, the Oxford Handbook of BGs (Colpan et al. 2010) - a comprehensive overview of the debate around research in BGs-does not feature a single chapter or index item referring to the corporate (social) responsibility of BGs.

This article is organized as follows. We first provide an overview over the phenomenon of BGs and their basic feature. We then characterize their CSR approach and explore existing theoretical frameworks regarding their potential to understand CSR in a BG context. We then highlight specific peculiarities of BGs in the context of CSR and their contribution to the public good. We then delineate some implications for the debate on CSR and the wider management 
literature which flow out of the analysis of BGs in this Special Issue. After briefly contextualizing the contributions of the Special Issue we then close with some perspectives for future research.

\section{The Understudied Phenomenon of Business Groups}

BGs play a large sometimes a dominant role in many economies. However, empirical research on their economic outcomes is scarce. The BG literature often divides BGs into two broad subcategories: network-type BGs and hierarchytype BGs although BGs around the world differ from each other widely with respect to organizational structure and scope (Yiu et al. 2007). BGs furthermore differ vastly, with regard to their geographical context and ownership structures. Figure 1 provides an overview over the different dimensions along which BGs have been analyzed.

Network-type BGs can be understood as "loose coalitions of firms that have no legal status (as a whole), and in which no single firm or individual holds controlling interests in the other firms" (Colpan and Hikino 2010, p. 19). These groups do not have a central apex unit that has the potential to exercise control for the entire group, e.g., the Japanese horizontal keiretsu groups. In contrast, a Hierarchy-type BG, "likens the BGs into a hierarchy in which a central unit controls legally independent operating affiliated firms that are tied together via several ties, including equity ties and interlocking directorates" (Colpan and Cuervo-Cazurra 2018, p. 3).

Hierarchy-type BGs are the most examined type of BGs in the management literature, which can be differentiated in two categories. Diversified BGs can be understood as "collections of legally independent enterprises, linked through equity ties and other economic means, which have a central unit at the helm that controls the affiliated enterprises in (technology or market-wise) unrelated industries" (Colpan and Hikino 2018, p. 6). Pyramidal groups, on the other hand, are "two or more listed firms under a common controlling shareholder, presumed to be the largest block holder voting at least 20 percent" (Morck 2010, p. 603).

The focus of attention on diversified BGs has been the unrelated diversification of such groups, whereas in the case of pyramidal BGs it has been the ownership structure and separation of control and cash flow rights (Colpan and Cuervo-Cazurra 2018). Although these groups may be analytically different, in reality diversified groups and pyramidal groups often overlap. For instance, the Tata group in India, the Koç group in Turkey, or the Wallenberg group in Sweden all illustrate unrelated product diversification and pyramidal ownership structure.

The formation of diversified BGs has been explained from two basic theoretical perspectives: the first stresses environmental factors that drive the existence of BGs and the other considers intra-group organizational factors (Colpan and Hikino 2010). The former perspective can further be subdivided into two. The first sub-perspective considers the immaturities and imperfections in product, capital, and labor markets in developing economies as the main cause for the development of BGs. Because external markets in developing economies are underdeveloped, BGs emerge to form intra-group markets and fill in the gaps in the outside markets and market institutions (Khanna and Palepu 1997; Khanna and Rivkin 2001). The second sub-perspective comes from political economy and considers government support and favor, such as direct subsidies and lower interest rates, as well as protection of the domestic market to a number of selected entrepreneurs to be the main cause for the development of BGs (Schneider 2010). Thanks to those privileges and advantages the particular entrepreneurs can enjoy, they are able to enter into a number of diverse industries, as has been illustrated by the South Korean chaebol during the 1960s and 1970s (Kim 2010). Third, and finally, another perspective focuses on the resources and capabilities
Fig. 1 Three dimensions and contingent factors in analyzing business groups

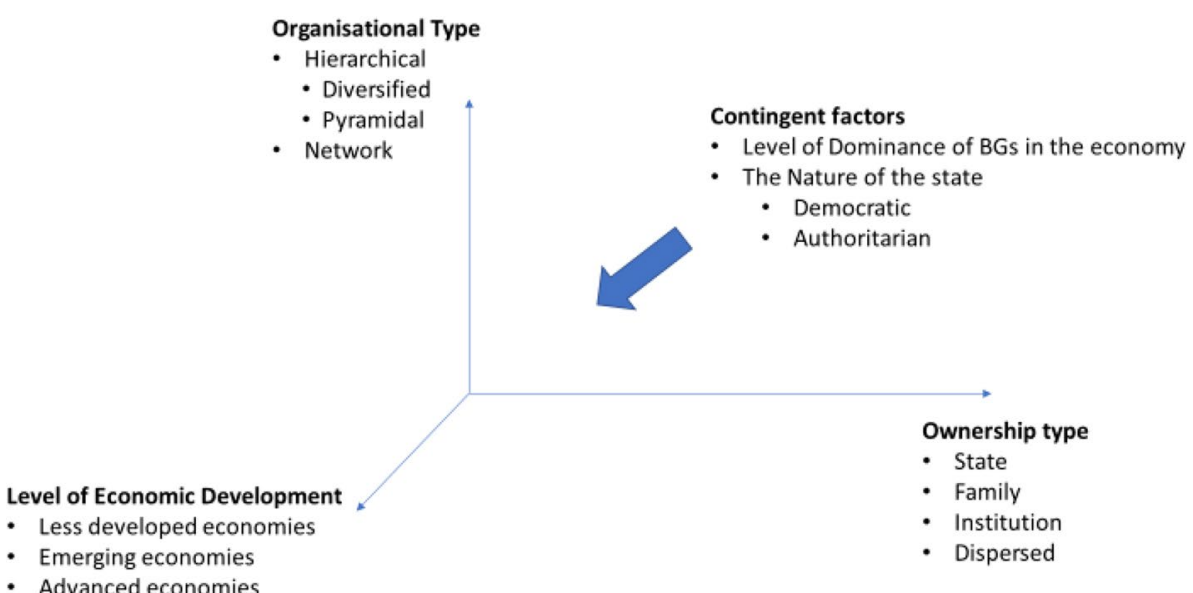


of entrepreneurs and their enterprises. It is because of the contact (with overseas enterprises and government in particular) and project execution capabilities that BGs in emerging economies develop; they can use their functional resources and capabilities to enter into a multitude of businesses regardless of the technological or market-related links between businesses (Guillen 2000; Kock and Guillen 2001; Cuervo-Cazurra, in this Special Issue).

Although BGs play a large role in several countries and often occupy a dominant presence in many emerging economies, empirical research on their economic outcomes is relatively scarce and mixed. The total value of a BG is difficult to calculate; BGs frequently include privately held firms that are not subject to public disclosure rules and even in the case of pyramidal groups with a public firm at the apex, holdings of the controller that fall outside of the group may not be visible. This opacity hampers efforts to estimate the economic performance of BGs reliably. While several studies report a positive association between BG membership and profitability (Khanna and Palepu 2000; Fisman and Khanna 2004; Claessens and Kodres 2014), these studies at most treat BG membership as a binary covariate, which drops out if one uses a firm fixed-effects specification (Ararat et al. 2014). Calculating the total social welfare that includes the value of benefits accrued to all stakeholders is even more difficult.

Some economists argue in favor of restricting, even dismantling BGs (Morck 2010) as they hamper competition, create systemic risks, enable controlling shareholders to capture political rents and influence political decision making. The ongoing debate whether BGs can enhance welfare, and if so under which circumstances, and within which contexts, is outside the scope of this paper, but we hope our findings and conclusions will inform further inquiry.

\section{CSR and the Public Good in a Business Group Context}

It is in some ways axiomatic, both to our argument in this overview article, and also to the arguments proffered by the papers in this Special Issue, to not define CSR in detail. In fact, by including the relation between BGs and what we refer to as the 'public good,' we intentionally cast our net wider than the plethora of existing CSR definitions and conceptualizations. Most of the literature, we argue here, is limited by notions of Anglo-Saxon business and specific corporate forms. Our interest is to include a generic understanding of business responsibilities to society that encompasses business activities that respond to social expectations and have an effect on the public good in the social, political, environmental, and economic environment of the firm. In applying such a broad perspective, we explicitly also include impacts of a detrimental or harmful nature on those environments-which rarely and only recently have entered the debate in mainstream CSR (e.g., Mena et al. 2016).

Group firms are different from stand-alone firms in a CSR perspective for several reasons. CSR strategies may be motivated by group-wide strategies and considerations, e.g., a $\mathrm{BG}$ with high level of investments in renewable energy, may sensitize all the firms in the group to climate change risks and encourage better environmental performance. Thus, it is not uncommon for BGs to have group-wide CSR themes as building blocks for their corporate strategies. Additionally, the effect of reputational benefits (and risks) can be group-wide.

A novel theoretical framing for the nexus of CSR and BGs can borrow from the "institutional void" paradigm as coined by Khanna and Palepu (2000), especially in emerging and developing markets. This institutional framing is combined with the resource-based view of the firm by $\mathrm{El}$ Ghoul et al. (2016) who report that CSR is more positively related to firm value in countries with weaker market institutions. This provides some support to the notion of CSR as a non-market mechanism through which firms can compensate for institutional voids. These arguments can be useful in developing a theoretical framing specific to CSR and BGs in emerging economies, but not necessarily in developed markets.

\section{CSR, the Public Good and the Role of Business Groups}

While several aspects of BGs such as their diversification conduct and pyramidal structures have been well researched, their business conduct and practices that fall under the notion of "corporate social responsibility" remain an understudied phenomenon. In order to establish a picture of the relevant literature, we first conducted a search of titles and abstracts for the term corporate social responsibility together with one of the following words: business group, pyramid, keiretsu, zaibatsu, chaebol, guanxi qiye, grupos economicos, conglomerates, and group affiliation. We searched all relevant articles through EBSCO and EconLit, as well as Google Scholar. We then deleted those articles that appear more than once in different search terms and locations. During a manual check of all identified articles, we excluded those that do not explicitly relate to CSR as such. Finally, we classified the remaining articles according to their national focus, sample period, keywords, manuscript type, and key findings related to CSR in BGs. Table 1 shows the relevant publications in chronological order.

As the table clearly shows, the number of studies that examine the CSR activities of BGs is rather limited. There appears to be some increase from the late-2000s onwards, coinciding with a surge of BG research in management. These studies however examine a diverse number of 
Table 1 Summary of publications related to the CSR of business groups (in chronological order)

\begin{tabular}{|c|c|c|c|c|c|}
\hline Author(s) (year) & National focus & Sample period & Keyword & Manuscript type & $\begin{array}{l}\text { Key findings related to CSR in } \\
\text { business groups }\end{array}$ \\
\hline O'Shaughnessy et al. (2007) & Japan & 1997-2000 & Keiretsu & Empirical & $\begin{array}{l}\text { Network affiliation in keiretsu } \\
\text { system does not share } \\
\text { common corporate social } \\
\text { performance (CSP) due } \\
\text { to low strategically shared } \\
\text { assets. The environment that } \\
\text { an industry operates in has a } \\
\text { larger impact on its CSP }\end{array}$ \\
\hline Talisayon (2010) & Philippines & $1970 s-2000 s$ & $\begin{array}{l}\text { Business group } \\
\text { Conglomerate }\end{array}$ & Conceptual & $\begin{array}{l}\text { There are large conglomer- } \\
\text { ates in Philippines that see } \\
\text { CSR activities as investment. } \\
\text { The diverse culture and the } \\
\text { reluctance of certain ethnici- } \\
\text { ties may be a hinderance to } \\
\text { more CSR activities being } \\
\text { implemented }\end{array}$ \\
\hline Kantabutra and Avery (2011) & Thailand & $2000 \mathrm{~s}$ & $\begin{array}{l}\text { Business group } \\
\text { Conglomerate }\end{array}$ & Conceptual & $\begin{array}{l}\text { Siam Cement Group was found } \\
\text { to comply with majority of } \\
\text { the Rhineland criteria and } \\
\text { practices. Sustainable leader- } \\
\text { ship principles are prevalent } \\
\text { in this large enterprise in } \\
\text { Thailand }\end{array}$ \\
\hline Oba (2011) & Nigeria & 2001-2006 & Conglomerate & Empirical & $\begin{array}{l}\text { There is a positive relationship } \\
\text { between company size and } \\
\text { CSR activities. The paper } \\
\text { argues that CSR is a western } \\
\text { philosophy that is not suitable } \\
\text { for developing countries }\end{array}$ \\
\hline Oh et al. (2011) & South Korea & 2002-2004 & Business group & Empirical & $\begin{array}{l}\text { Ownership by top managers } \\
\text { has negative relationship with } \\
\text { CSR ratings due to complex } \\
\text { structure of chaebols. Large } \\
\text { chaebols are powerful enough } \\
\text { to resist any CSR reforms } \\
\text { introduced by the government }\end{array}$ \\
\hline Pegg (2012) & China & $1990 \mathrm{~s}-2000 \mathrm{~s}$ & Business group & Conceptual & $\begin{array}{l}\text { CSR activities adopted by the } \\
\text { Chinese are different from the } \\
\text { Western countries. Large oil } \\
\text { companies in China see CSR } \\
\text { in the oil industry in Africa } \\
\text { as the responsibility of the } \\
\text { African government }\end{array}$ \\
\hline Choi et al. (2013) & South Korea & 2002-2008 & Business group & Empirical & $\begin{array}{l}\text { The relationship between CSR } \\
\text { ratings and level of earnings } \\
\text { management is weaker for } \\
\text { chaebol firms and firms with } \\
\text { highly concentrated owner- } \\
\text { ship. CSR practices can thus } \\
\text { be abusively used by business } \\
\text { group affiliated firms to } \\
\text { conceal their poor earnings } \\
\text { quality }\end{array}$ \\
\hline
\end{tabular}


Table 1 (continued)

\begin{tabular}{|c|c|c|c|c|c|}
\hline Author(s) (year) & National focus & Sample period & Keyword & Manuscript type & $\begin{array}{l}\text { Key findings related to CSR in } \\
\text { business groups }\end{array}$ \\
\hline Guereña (2013) & Paraguay & 2013 & Grupos economicos & Empirical & $\begin{array}{l}\text { DAP group in Paraguay has } \\
\text { taken an active role in CSR. } \\
\text { However, the use of geneti- } \\
\text { cally modified soy seeds and } \\
\text { agrochemicals has caused } \\
\text { more harm than benefits to } \\
\text { the environment and society }\end{array}$ \\
\hline Dávila and Dávila (2014) & Colombia & 1911-1985 & Business group & Historical & $\begin{array}{l}\text { Fundación Social (FS) group } \\
\text { has complex CSR strategies } \\
\text { that balance their aid towards } \\
\text { social and economic issues } \\
\text { with financial management } \\
\text { activities in Colombia }\end{array}$ \\
\hline Hoque et al. (2014) & Sweden & $2000 \mathrm{~s}$ & $\begin{array}{l}\text { Business group } \\
\text { Conglomerate }\end{array}$ & Conceptual & $\begin{array}{l}\text { The CSR strategy of Volvo } \\
\text { Group is based on its Code of } \\
\text { Conduct, which Volvo strictly } \\
\text { adheres. Volvo Group's } \\
\text { CSR strategy has helped the } \\
\text { enterprise to gain trust among } \\
\text { stakeholders }\end{array}$ \\
\hline Shah (2014) & India & 2012-2013 & $\begin{array}{l}\text { Business group } \\
\text { Conglomerate }\end{array}$ & Empirical & $\begin{array}{l}\text { Tata group has CSR policy } \\
\text { which they strictly follow. } \\
\text { Tata group was able to link } \\
\text { business practices with social } \\
\text { well being in an effective way }\end{array}$ \\
\hline $\begin{array}{l}\text { Montecchia and Di Carlo } \\
\text { (2015) }\end{array}$ & Italy & $2010 s$ & Business group & Empirical & $\begin{array}{l}\text { Affiliates tend to adopt similar } \\
\text { corporate social disclosure } \\
\text { (CSD) as their parent if their } \\
\text { products are related. Busi- } \\
\text { ness groups with unrelated } \\
\text { products tend to follow } \\
\text { the CSD of businesses in a } \\
\text { similar industry. Exoisomor- } \\
\text { phism pressure is deemed as } \\
\text { the main reason for different } \\
\text { levels of CSD }\end{array}$ \\
\hline Cho et al. (2015) & South Korea & 2005-2010 & Conglomerate & Empirical & $\begin{array}{l}\text { Chaebols tend to adopt CSR } \\
\text { more efficiently than non- } \\
\text { chaebols. Chaebols has the } \\
\text { tendency to fit CSR activities } \\
\text { adopted domestically into } \\
\text { their international diversifi- } \\
\text { cation strategies. However, } \\
\text { domestic CSR activities will } \\
\text { reduce if international diversi- } \\
\text { fication increases. }\end{array}$ \\
\hline Agarwal (2016) & India & $2010 \mathrm{~s}$ & $\begin{array}{l}\text { Business group } \\
\text { Conglomerate }\end{array}$ & Historical/empirical & $\begin{array}{l}\text { Aditya Birla Group started } \\
\text { its CSR activities by giving } \\
\text { social and economical aid to } \\
\text { the people in India. The group } \\
\text { later also took initiatives by } \\
\text { being more environmental } \\
\text { friendly in their operation } \\
\text { processes }\end{array}$ \\
\hline
\end{tabular}


Table 1 (continued)

\begin{tabular}{|c|c|c|c|c|c|}
\hline Author(s) (year) & National focus & Sample period & Keyword & Manuscript type & $\begin{array}{l}\text { Key findings related to CSR in } \\
\text { business groups }\end{array}$ \\
\hline Marano et al. (2016) & Emerging markets & 2004-2011 & Business group & Empirical & $\begin{array}{l}\text { CSR reporting by emerging } \\
\text { market multinationals is an } \\
\text { effective way to overcome the } \\
\text { negative perceptions in host } \\
\text { countries about firms' ability } \\
\text { to conduct legitimate business } \\
\text { activities. Business group } \\
\text { affiliation does not influence } \\
\text { CSR reporting intensity }\end{array}$ \\
\hline Min (2017) & South Korea & 2001-2014 & Business group & Empirical & $\begin{array}{l}\text { Chaebols see social evalua- } \\
\text { tion to be as importance as } \\
\text { innovation after nation wide } \\
\text { economic crisis in } 1997 . \\
\text { The research shows how the } \\
\text { effects of business groups } \\
\text { on institutional logics are } \\
\text { mediated through the focus } \\
\text { on CSR and materialistic } \\
\text { innovation }\end{array}$ \\
\hline Sheikh (2017) & India & $1920 s-2010 s$ & $\begin{array}{l}\text { Business group } \\
\text { Conglomerate }\end{array}$ & Historical/review & $\begin{array}{l}\text { This paper examines the scope } \\
\text { of CSR activities that Bajaj } \\
\text { Group is involved in. The } \\
\text { Bajaj Group has developed } \\
\text { over } 40 \text { public charitable } \\
\text { trusts engaged in CSR activi- } \\
\text { ties }\end{array}$ \\
\hline
\end{tabular}

emerging economies especially in Asia, and particularly South Korea.

Most studies argue BGs can effectively use CSR to justify their dominant presence in the economy and to further gain trust and acceptance of their status within society. For instance, Min (2017) argues that following the 1997 financial crisis, Korean chaebol affiliated firms invested more into CSR activities to be more community oriented than non-chaebol firms. As Korean firms experienced threats to their legitimacy and sustainability during the financial crisis, chaebol firms effectively used CSR strategies to regain their social legitimacy. Cho et al. (2015) also argues that chaebols tend to adopt CSR more efficiently than non-chaebols. Chaebols also have the tendency to fit CSR activities, adopted domestically, into their international diversification strategies. Studies looking at other nations such as India and Sweden, e.g., the studies by Shah (2014) that examine the Tata group and Hoque et al. (2014) that analyze the Volvo group respectively, similarly argue that the CSR strategies of these groups have helped the enterprises to gain trust among their stakeholders and to curb potential regulatory interventions.

There are, however, a number of studies that contradict the above view. These indicate that CSR investments by BGs are less extensive than non-BG firms and are furthermore used in superficial and socially detrimental ways. For example, Oh et al. (2011) argue that managers in family-owned
BGs in South Korea are likely to use their power solely to enrich the family at the expense of other public stakeholders. This, in the end, reduces the BG-affiliated firms' CSR investments as well as CSR ratings. Choi et al. (2013) further examined the relationship between CSR ratings and the level of earnings management; this investigation found that the relationship is weaker for chaebol firms and firms with a highly concentrated ownership. The authors argue that CSR practices can thus be used abusively to conceal poor earnings quality by Korean BG-affiliated firms. CSR activities by BG-affiliated firms may therefore be employed to hide opportunistic management behavior.

\section{Applying Existing CSR Frameworks to Business Groups}

So far, we have argued that BGs are quite different institutions compared to the forms of business which dominate much of the Anglo-Saxon discourse in business studies. In the preceding paragraph we have also adumbrated some of their core activities and exposure to CSR and the public good. Essentially, one of our goals with this Special Issue is to shed more light, descriptively, on the nature of the firm in many emerging and developing economies. Ultimately, as some of the papers in this Special Issue attempt to varying degrees, the goal is to theorize CSR-related activities 
of BGs and propose an alternative account of the nature of CSR in BGs.

To this end, it is rather pivotal to first analyze and probe the potential of existing theoretical approaches to CSR for the context of BGs. Such a discussion appears useful, and is in fact necessary, for several reasons. Firstly, much of the work on CSR - even if generated using a rather different type of firm as an empirical backdrop-may also have a partial application to BGs. In that sense, research in this new area should be cautious to avoid 're-inventing the wheel.' Secondly, and even more important for theory-building, it is essential to identify the limits of existing theorizations of CSR, to build a more astute theoretical understanding of CSR in BGs. We are aware that our work here represents just a start of this project and we offer our analysis for future research on the trajectory of theorizing CSR in a BG context.

\section{Carroll's Model of Corporate Social Responsibility}

Definitions of, and approaches to theorize, CSR abound; they mainly differ in that they reflect specific social contexts (the ' $S$ ' in CSR) in which firms assume their social responsibilities. One of the more generic theorizations however, which to some degree encompasses most CSR definitions and has dominated the literature regarding CSR and strategy for almost four decades, is Archie Carroll's 'pyramid of CSR' (Carroll 1991). Carroll argues that CSR is a construct that can be disaggregated into four main aspects, which successively build on each other whereby the fulfillment of each area of responsibility is a pre-condition for the subsequent area of CSR. These areas are, first, 'economic responsibilities,' followed by 'legal,' 'ethical,' and 'philanthropic' responsibilities.

While referring to the literature on Carroll's framework (e.g., Carroll 1998; Schwartz and Carroll 2003), a few remarks appear appropriate. It appears that philanthropy, in almost in most regions of the globe where BGs are significant economic players, takes a preceding role for BGs. This argument concurs with Visser's (2008) adaptation of the Carroll pyramid, for a developing country context; although Visser questions whether this is linked to a specific corporate form, such as BGs (see below). Rather than being the metaphorical 'icing on the cake,' philanthropy is a core social expectation which is not just 'expected' but in fact 'required' (to use Carroll's attributes) from companies. In addition, philanthropy is not only a first-order response, but also a legitimacy instrument that represents a "compensation" or "pay off" to society by the powerful owners of the companies for the privileges and protections offered to them by the state (Ararat 2005; Bugra 1994).

Carroll's model affords therefore some leeway in structuring and identifying the social responsibilities of BGs. Regarding the prioritization of responsibilities, as well as to the specific demands and social expectations placed on BGs, the model seems to largely overlook and misemphasize different aspects of those four elements of CSR.

\section{Contemporary Approaches to Theorize CSR}

Next to generic notions of CSR, a number of approaches have been developed over the last decades, casting a broader net around the responsibilities and public roles of business in society.

- Stakeholder theory (Freeman 2010) in its origins has rather strong roots in the (American) model of a shareholder governed firm, based on the classic separation between ownership and control (Berle and Means 1932). In essence, stakeholder theory challenges the agency model in which shareholders are the residual claimant on the firm and the objective of maximizing shareholder value ultimately maximizes the total welfare. Stakeholder thinking replaces agency thinking with a model whereby all parties affected by, and who can affect the success of the firm, have a legitimate claim on the firm to consider their interests. Much of the literature engaging with CSR in developing countries and, in particular BGs, accepts stakeholder theory as an appropriate framework (e.g., Rossouw 2005).

- Following the popularity of the 'citizenship' metaphor, corporate citizenship has gained traction as a theoretical concept in the broader CSR literature (Crane et al. 2008; Matten and Crane 2005). The gist of this debate however sees corporations closer to the role of governments than the role of citizens (see below). This is derived from the idea that the corporate role in society, manifested in some-but not all_-of the CSR activities, resembles strongly the role of governments in their role of guaranteeing and catering to citizen's entitlements in a liberal democracy. As we will discuss in more detail further below, the extent of the provision of social goods by BGs, as well as the BGs power to influence and govern markets for goods, labor, and capital, corporate citizenship provides a lens through which we can explain and conceptualize some of the responsibilities of BGs in society.

- Over the last decade a new debate has emerged in the wider CSR discussion regarding the corporation as a political actor. One predominant term that has been coined by some authors is that of 'political CSR' (Scherer and Palazzo 2011; Scherer et al. 2016), to describe the role of private businesses in wider societal governance. This debate refers to the political processes resulting in authoritative allocation of values and resources in society-a role initially ascribed to governments, certainly in liberal democracies. While Scherer and Palazzo (2007) 
initially confine this role to Habermasian processes of deliberation, the wider debate encompasses a participatory role for business, in a number of arenas where decisions about the wider governance of society are taken. This lens has its particular application at a descriptive and normative level, with regard to how BGs participate in society, together with governments and civil society.

We will later evaluate the potential and possible limitations of those extant theoretical lenses on CSR, in the context of BGs, but first, we will identify and discuss some of the core issues and empirical peculiarities of CSR in a BG context

\section{Core Issues in Analyzing Business Groups from a CSR Angle}

The papers in this Special Issue highlight some of the specifics of CSR in BGs. Emerging themes focus around (1) the relation between CSR and the governance of the BG, most notably the influence of ownership, (2) the dominant role and specific nature of philanthropy as core expression of CSR in BGs, and (3) the corporate (ir-)responsibility in the market power and control of BGs and their relations to governments.

\section{Corporate Governance and the Role of Ownership}

The governance of companies has been a key concern from the perspective of economic responsibilities. The primary governance problem in controlled firms concerns the agency problems between controlling shareholders-the "common controller' in BGs and public investors. In BGs, the common controller has an incentive to monitor and discipline management while enhancing the collective value of affiliated firms. In weak institutional settings a controller with a good reputation can facilitate trust among investors, customers, and suppliers. Common controllers may however also have the means to divert value from group firms to outside of the group at the expense of minority investors (Holmen and Hogfeldt 2009). The propensity of value diversion and overinvestment is higher in pyramidal BGs where voting rights are separated from cash flow rights, especially at lower levels of the pyramid where the controller can control the firm without risking a proportionate amount of capital. The diversion of value can take many forms, including related party transactions that favor the controller, or excessive compensation to the managers affiliated with the controller (Bae et al. 2012). The propensity to divert value may result in large discounts in the market value of individual firms within the group (Claessens et al. 2002a, b).
A particular corporate governance issue from a CSR perspective is the opacity of BGs' governance arrangements and the means of exercising coordination and control. This opacity is partly attributable to the non-existence of pyramidal BGs in the US and UK, whose corporate governance disclosure norms as the most developed capital markets have inspired the rest of the world. The concepts of "piercing the corporate veil" and the "shadow board"-where the actual directors of a company are accustomed to act in accordance with an outsider's directions or instructions-have not been explored in a BG context and thus have not been adequately addressed in corporate governance regulations around the world with some exceptions [e.g., see Reich-Graefe (2005) on the German Stock Corporation Act, and Cankorel (2015) on the Group of Companies in Turkish Commercial Code].

Another corporate governance concern is value diversion from companies to charitable foundations whose income consists of donations by the BG-affiliated firms. These foundations, frequently named after the founders, enhance the reputation and the credibility of the controlling shareholder, frequently a family, at the expense of minority investors (Kim et al. 2017; Bae et al. 2012). Whether the good reputation of the controlling shareholder enhances the value of BG firms is an empirical question. It is possible that CSR investments may decrease firm value when they represent an opportunistic exploitation of resources by controlling shareholders (Pagano and Volpin 2005; Masulis and Reza 2014).

The first two papers discussing the specific governance structures of BGs and their effect on CSR draw on data from Korea and India - two countries where the local economy is substantially influenced by BGs.

Choi, Jo, Kim, and Kim's paper in this Special Issue attempts to answer two related questions: whether the CSR behaviors of group firms are different from those of nongroup firms; and if so, whether and how such behaviors are related to the ownership disparity between cash flow rights and control rights ('wedge') associated with the propensity to expropriate (Villangola and Amit, 2009). They first provide convincing evidence that group affiliation is associated with higher overall CSR, proxied by the environmental and social performance ratings of the affiliated firms. Deviation of control rights from cash flow rights in group firms is however associated with lower CSR. They argue that these results indicate that opportunistic rent-seeking behaviors by controlling shareholders may reduce the resources available for CSR in affiliated firms. An interesting result of their study is that although BG affiliation is associated with a lower Tobin's $Q$, it may enhance firm value if a group firm practices CSR consistently. The authors, furthermore, provide supporting evidence on the effect of long-term, consistent CSR as a shield for the firms from reputational damages, as recently documented by Shiu and Yang (2017), is stronger 
for group firms especially at times of group-specific negative events, buffering them from bad outcomes.

In a similar comparative vein, the paper by Ray and Chaudhuri examines whether BG-affiliated firms differ from non-BG-affiliated firms in their corporate sustainability strategy (CSS). They also look at how the BG affiliation influences the relationship between stock of fungible resources and CSS of firms. Using a proprietary data set of 163 Indian publicly listed firms (that include both BGaffiliated and non-affiliated firms), the authors show that BG-affiliated firms tend to adopt environmental and social sustainability strategies more than non-BG firms. The major factors contributing to BG-affiliated firms adopting more CSS strategies are: BGs tend to focus more on building and maintaining group-level identity; they are less sensitive to short-term financial performance; BGs have historical roles in filling institutional voids; and they benefit from the interfirm network that they are parts of. The authors also show that stock of fungible, firm-level resources are less important for the CSS of BG-affiliated firms, as they have access to the BG's network; they can readily exploit and benefit from the resources within their network.

The paper by Terlaak, Kim, and Roh focuses in particular on the thorny issue of family ownership and its relationship to CSR. CSR-disclosure, in particular, is an ambiguous issue in BGs. Family ownership, in general, makes BGs more secretive and lowers their propensity for disclosurewith all its negative and ethically questionable implications. The findings of this paper point to aspects beyond this tacit assumption; however, by examining levels of family ownership and family leadership of the BG, the paper demonstrates that higher levels of ownership, and the engagement of a family member as CEO or in other leading group-roles, enhances levels of disclosure. The paper points to an interesting conclusion: if a certain family is closely engaged and actively involved in a BG, the positive effects of reputational gains of CSR appear more attractive, as they directly enhance the public perception not just of a BG, but also of its controlling family.

\section{Corporate Philanthropy as a Dominating Form of CSR}

Three papers in this Special Issue focus on philanthropy and the provision of social goods as a main form of CSR of BGs-mostly linked to their dominant presence in developing and emerging economies.

A theoretical paper by Cuervo-Cazurra conceptualizes the evolution of CSR investments by BGs, in different stages of economic development, based on the interaction between two drivers: the level of infrastructure deficiencies and the cost of externalities resulting from their economic activities. His model foresees a quadratic "CSR investment level" function based on the level of economic development. In underdeveloped economies, CSR investments are predicted to be higher and focused on the social dimensions of CSR through philanthropic investments. As economies emerge, and infrastructure deficits become lower, CSR investments evolve to a richer set of environmental and economic responsibility, albeit at a lower level. The level of CSR investment goes up again as economies become advanced. In advanced economies CSR investments become a source of innovation and competitive advantage for group firms, as they address and minimize negative externalities specific to their respective group. The model provides a useful theoretical reference frame for studying the engagement of BGs in furthering the public good with a historical perspective.

Much of the CSR of BGs in developing economies targets infrastructure deficiencies, social needs-and thus in general-philanthropy-as illustrated by some of the empirical contributions in this Special Issue. This is also consistent with the prevalence of BGs in developing and emerging economies, where hierarchy and networks, rather than functioning institutions and markets, play a leading role in ensuring the efficient organization of economic actors.

The paper also highlights the necessity for further research into the specific nature of the firm in these economies: while comparative studies of CSR in developing countries abound, there is very little attempt to explain those specific forms of CSR with the specific nature of those firms (e.g., Jamali and Karam, 2018. The proposed framing might offer a fruitful basis for further investigation into these issues and to open the 'black box' of BGs, which still characterize much of the literature on CSR in developing economies (Jamali 2016).

The paper by Griffin and Youm casts light on two specific differences between CSR in BGs and CSR as it is discussed in most of the literature. This paper firstly illustrates that the business-case argument for CSR is of little importance to BGs, as they demonstrate with their sample of Korean chaebols. The main argument for BGs engaging in CSR activities is the search for social legitimacy-as large BGs obviously have strong visibility, presence, and power in the Korean economy. The paper then illustrates that the core focus of CSR for many BGs is still philanthropic or charitable contributions - a finding echoed by other studies looking at CSR in a comparative perspective (Witt and Redding 2013). This also relates to an earlier point raised, regarding the relative dearth in studies, related to the accessibility of data and the transparency with which CSR is conducted by BGs. The authors suggest that this is because philanthropy as part of CSR, is more seen as part of the general, institutionalized role of BGs in Korean society-rather than a specific activity deemed CSR. This social role assigns corporations a more implicit role in their pro-social behavior, 
rather than perceiving this as a strategic choice and part of managerial discretion.

High-quality corporate giving data are available in Korea because companies report their charitable contributions in their audited financial statements. Making use of this data, Oh, Chang, Lee, and Seo's investigation sheds some light on the relationship between philanthropy, and related party transactions between publicly listed firms within a group. The authors investigate the relationship with the theoretical lens of the "attention-based view of the firm" (Ocasio 1997). Simply put, their results suggest that publicly listed BG firms with higher levels of "intragroup" sales have lower levels of corporate philanthropy. Using data on Korean BG firms, their results suggest that decision-makers increase the level of corporate philanthropy, at the publicly listed groupfirm level, when the firm is less dependent on intra-group sales and more dependent on external markets. This negative effect of intra-group sales on philanthropy is positively moderated by the level of presence of outside (independent) directors above the level of regulatory requirement, and the level of foreign investor ownership. This suggests that the level of corporate philanthropy decreases when a firm opts for increased monitoring by outsiders. These results may support the view that BGs firms may not be homogeneous with respect to their corporate social responsibility practices, but this is subject to the specific role each firm plays in internal markets, the relative importance of external markets, and the strength of corporate governance.

\section{Market Control and Government Relations}

One of the interesting aspects of discussing CSR in a BG context is that, next to BGs' considerable engagement in philanthropy, their broader impact on society goes beyond the classic 'toolbox' of CSR (according to textbook definitions such as Carroll's, above). In many countries where BGs operate, their dominant social role is that of providing access to vital goods and services. They have, as such, historically enjoyed special relations and protections from governments in many countries, and due to their often market-dominating role, have wielded considerable control over the economy. Addressing Khanna and Yafeh's (2007) meanwhile classic question, as to whether they are 'paragons' or 'parasites,' is therefore also vital for the assessment of their contribution to the public good beyond their explicit CSR policies and activities. Quite a strong element of BG's CSR can be referred to as 'implicit CSR' (Matten and Moon 2008), i.e., that BGs contribute to the public good just through their institutionalized role in their particular economic context. There are two papers in this Special Issue which deal with this ambiguous impact of BGs on the public good and highlight what we could refer to as the dark side of CSR by BGs:
The paper by Pattnaik, Quiang, and Gaur then casts a somewhat different light on the role of BGs in emerging markets. In the language of Carroll's model of CSR (see above), the authors argue that BGs play a rather ambiguous role with regard to the 'economic responsibilities' of the firm.

While BGs often provide essential goods and services in developing and emerging economies, their size and control of markets results in relative competitive disadvantages for smaller, independent businesses. Pattnaik et al. examine such market control in the Indian context and provide a differentiated picture of the nature of such market dominance of BGs, including entry barriers for new market entrants they can impose. Overall, they find that concentration of industrial investment activities by BGs is economically counterproductive in the long term-due to the entry barriers that they create for unaffiliated firms and smaller BGs. The paper extends the earlier analysis of the effect of BGs on capital markets (Pattnaik et al. 2013) to product markets. It also contextualizes the influence that BGs can wield on regulators and, in general, the governments of those countries by dint of their size and basic provision of vital goods. As such this paper also hints at the political role BGs might assume in their specific societal contexts.

An interesting inquiry by Su and Tan focuses on off-shore companies in tax-havens in BGs. Having off-shore companies in tax-havens may enable group firms to bypass some market transaction costs, overcome institutional constraints, and protect assets against volatile markets. Such arrangements may, however, also provide the opportunity to evade taxes and disguise unethical or illegal conduct—such as political donations and bribery. Prior research suggests that larger and more diversified BGs are more likely to engage in self-dealing, tunneling, and political rent-seeking (Claessens et al. 2002a, b). Based on data from Taiwan, Su and Tan find that more diversified BGs are also more likely to establish off-shore companies in tax-havens. Their results suggest that pro-social orientation, measured by the level of BG's charitable establishments, has a negative moderating effect on this relationship for internationally diversified BGs, although it has no effect on the BGs with high levels of industry diversification.

\section{Business Groups and Their Social Role as an Understudied Phenomenon}

By comparison, the phenomenon of BGs and their role in CSR as well as their relation to the public good has met limited scholarly interest. One could argue that academic institutions and research work in many of the countries in which BGs are dominant players, on the whole, have only recently found a stronger voice in the global, Anglo-American 
discourse on management research-in general and in particular in CSR research.

Another reason might also be, since BGs are very strongly embedded in a particular culture and local institutional frameworks, access for global researchers could often be mired by obstacles, including language barriers, lack of networks, and limits in an intimate understanding of local contexts. Those regions of the globe where BGs are pivotal players in the economy are, however, also the areas where we currently see the largest growth in academic research, in parallel with those regions' increased collective economic significance. It is our hope that a Special Issue that deliberately identifies BGs, as a specific corporate form and the focus of investigation, can open a discourse that might inform and inspire future research in this area.

\section{Business Groups and the Theory of the Firm}

Building on the last observation it has to be emphasized that we have indeed seen a surge of research into CSR in developing or emerging economies (Jamali and Karam 2018). Much of this literature however often uses a very blunt application of theories and concepts generated by the global discourse in the West. While some work in this area appreciates and conceptualizes the specific institutional context of developing countries, the tacit assumption of much of the work is still that businesses in those parts of the world are basically the same as in developed/Anglo-Saxon economies. The firm, more often than not, is treated as a black box. Data limitations are also constraining; prevalent disclosure standards are largely built upon the experiences of developed markets and do not recognize BGs as a reporting entity. Consequently, empirical studies typically operationalize BG affiliation as a dummy variable at the individual firm level. Even then, validated data on group affiliations from country specific institutions or stock market guides is only available in a few countries such as Korea, Taiwan, and India. This explains the relatively richer literature on BGs in those countries, and the focus of submitted papers to our call for papers on BGs and CSR. In this Special Issue we hope to have at least opened the black box somewhat, to allow an appreciation of the specific corporate forms in many of those contexts and regions. We argue that it is vital to understand the idiosyncratic nature of business in these contexts to explain and theorize their CSR approach and their impact on the public good.

It is here where we would argue that this Special Issue can make not just a contribution to scholarship on CSR—but more generally beyond this-can feed in and inform ongoing debates on the nature of the firm and its boundaries. For quite some time, management academia has raised the question whether we still base our academic field on an adequate theory of what a firm actually is. Most recently, since the financial crisis of 2008, but already earlier in the aftermath of the crises around 2000, anxieties around the model of the firm's adequacy have been increasingly subject of an emerging debate (Baars and Spicer 2017; Barley 2007; Barton et al. 2016; Child 2002). These concerns revolve particularly around an apparent lack of social responsibility of business as an institution, and its detrimental influence on the public good. The latter as been exemplified by the ripple effects of the financial crises globally.

One of the reasons that we would posit why BGs have so far played a marginal role in those debates is related to this challenge; they do not fit into the current still dominant model of the firm in management academia. One of the milestone contributions in these ongoing debates by Donaldson and Walsh (2015) might serve as an illustration for why BGs have played such a marginal role in the debate. It may also contribute to our understanding of how a more adequate theory of the firm might open a larger conceptual space to integrate BGs, as one pivotal institutional template for what a firm looks like.

Donaldson and Walsh suggest a new theory of business which, they argue, empirically and normatively provides a more realistic and societally more beneficial understanding of the firm (see Table 2). If we look at the characteristics of neo-classical theories of the firm, it is very clear by now

Table 2 Comparison of neo-classical theories of the firm with more a more contemporary approach to the theory of the firm in a business group context (based on Donaldson and Walsh 2015, p. 197)

\begin{tabular}{|c|c|c|c|}
\hline & Neo-classical theories of the firm & A theory of business (Donaldson/Walsh) & The perspective of business groups \\
\hline Purpose & Maximize firm value & Optimize collective value & $\begin{array}{l}\text { Optimize collective value; } \\
\text { Maximize own legitimacy }\end{array}$ \\
\hline Accountability & To the law and the firm's owners & To all participants in a particular business & $\begin{array}{l}\text { To: } \\
\text { Society at large; } \\
\text { Controlling shareholders }\end{array}$ \\
\hline Control & Guard against self-seeking with guile & Prohibit assaults on participants' dignity & $\begin{array}{l}\text { Guard against self-seeking of the controller; } \\
\text { Protect identity }\end{array}$ \\
\hline Success & Shareholder wealth creation & Optimized collective value & $\begin{array}{l}\text { Optimized collective value; } \\
\text { Maximized reputational resources }\end{array}$ \\
\hline
\end{tabular}


that many of those features have only a limited application to BGs - if at all. Certainly, with regard to purpose, accountability, or success, BGs differ at times quite considerably from this extant theoretical model.

Examining what Donaldson and Walsh suggest as an alternative theory of business, it becomes immediately clear, in the light of our discussion in this paper so far, that empirically many BGs come quite close to these features. This applies most notably to the purpose of the firm: many BGs (particularly in emerging economies) understand their role in society in a much more comprehensive way than just maximizing the value of the firm. They also consider future generations (for instance in the case of family ownership, see Weston 2016) or a wider constituency of communities affected by the BG. This wider purpose for many BGs also informs the scope of accountability of the firm, as some of the papers in this Special Issue demonstrate: In particular BGs which have a longstanding tradition in CSR (or their predecessors such as paternalism), see the dignity of their wider community at its core. A textbook example is certainly the Tata BG where management sees itself intricately involved in 'nation building' - initially against British-colonial rule. In a similar vein the notion of collective value, or in other words, a contribution to the public good, is something BGs are much more familiar with. Many BGs see themselves rather as an intricate part of a certain societal, national, or regional context to which to contribute at various levels. This may be related to the fact that diversified BGs are exposed to the spill-over effects of externalities from one industry at a cost to other industries that they operate in; they are long-term oriented, and the health of the collective business is more sensitive to country risks. From this perspective the reference to the controlling shareholders of BGs as 'national owners' is analogous to the conceptualization of global diversified investors as 'universal owners' (Hawley and Williams 2007).

\section{Business Groups and Their Responsibility for the Public Good}

In the light of Donaldson and Walsh's suggestions, theorizing the responsibility of BGs for the public good reflects substantial features of those organizations. For instance, as we discussed in the context of Carroll's model of CSR, and as some of the papers in this SI point out, the economic goals of BGs are often much more long-term oriented. They are much less a reflection of immediate consumer demands in the market and the short-term return interests of shareholders.

In a similar vein, the clear separation between 'the firm' and 'shareholders' or 'owners' - as inherent in much of stakeholder theory (Freeman 2010) - is somewhat more complex in the case of BGs. In BGs, the controlling owners often have the formal or informal authority to appoint the majority, if not all board members, even if they do not own the majority of the shares. In family-controlled BGs the controlling family members frequently sit on the boards themselves. Independent directors that are mandatory in most countries are rarely genuinely independent in controlled BGs (Bebchuk and Hamdani 2018; Puchniak and Kim 2017). With the exception of the lower-level firms in pyramidal BGs where ownership and control are relatively more separated, the term "owner-control" appears a more suitable characterization of BG governance.

Looking at the aspect of control and success in Donaldson and Walsh's framework we see some strong reflections of corporations as citizens. Citizenship and the 'dignity' of citizens encompasses a bundle of rights which differentiate into social, civil, and political rights. With regard to social rights, i.e., citizen's entitlement to access basic elements of welfare state provisions, we see that the philanthropic engagement of many BGs is directly engaging with those social rights. Access to health, education, affordable transport, basic social security are all activities undertaken by government in post-war liberal democracies. In contexts of poor governance, poverty, or institutional voids however, we see BGs stepping into the lack of governmental catering to these rights. Similarly, we see a role of BGs in dealing with civil rights, i.e., rights to protect individual freedom from external interference. These include property rights (including free markets for goods, labor, and capital), freedom of movement, freedom of speech, and freedom from bodily harm. In this area, the picture is somewhat mixed. In some cases, large BGs might play a role in providing these rights, as in respecting property rights of landowners or implementing health and safety measures. One might also argue however that their power and influence in their respective environments puts them in a role that infringes some of these rights, as the paper by Pattnaik et al. in this Special Issue suggests.

A third element of citizenship rights are political rights, i.e., the right to participate in societal governance processes. This relates to the notion of political CSR and-in the context of BGs-is quite a powerful conceptual lens to theorize CSR-related activities. The size, power, market dominance, and accumulated capital associated with these firms put them in a position to play a key role in the governance of their respective societal contexts. A key role here falls to CSR-related policies and activities (or the absence thereof). These policies and activities can be internally orientedsuch as the way BGs treat their employees-or externally oriented such as their environmental policies or level of compliance with the law. Beyond that and in particular in the way-for instance, BGs govern markets, structure access to and allocation of capital, or collaborate with governments in shaping the legal framework for the economy-they wield 
considerable political power in their respective societal environments. Some of the contributions in this Special Issues speak quite unequivocally to such a role.

The latter aspect, however, also points to some limits of extant concepts of CSR, and the context of BGs helps to unmask their compatibility with, if not origin in, a notion of the firm that sees CSR more as a 'fix' to the existing system, rather than a quest for an alternative understanding of the firm.

With regard to Carroll's model, these differences become obvious if we scrutinize the 'legal' responsibilities of the firm. In the Carroll model these basically boil down to compliance. As we outlined above, BGs however, with their intricate relations to governments in their operational jurisdictions, are less like passive pawns in the hands of lawmaking institutions. Rather, they often assume a role that actually actively shapes the local legal framework. Moreover, in a context of institutional voids - to which a sizeable number of BGs owe their existence and operational discretion-compliance with legal demands and rules is often a rather negligible social expectation on these businessesespecially when governments lack public acceptance.

Closely related to the previous point, the underlying purpose of BGs is vastly different from what underlies stakeholder theory, certainly in its descriptive and instrumental versions (Donaldson and Preston 1995). From this perspective, stakeholder theory is often applied as a more realistic model for the firm to achieve its purpose, i.e., maximizing profits and shareholder return in the long term. Certainly, a large section of the CSR literature that refers to stakeholder theory is shot through with such business-case thinking; 'roping' in stakeholders and respecting their interest is just a 'smart' way of attaining this ultimate goal. As we discussed above, the purpose of many, if not most, BGs is somewhat more complex. Famous here is the often-quoted statement by Jamsetji N. Tata, Founder of the Tata Group in India: 'In a free enterprise, the community is not just another stakeholder in our businesses, but is in fact the very purpose of its existence' (Tata and Matten 2016). BGs pursue a multiplicity of goals, and profitability is not always the dominant concern, certainly in the short or mid term.

A further aspect where the discussion of BGs reveals some of the limits of extant approaches to CSR is the motivation of stakeholder engagement in BGs. The original model of stakeholder theory assumes some kind of 'enlightened self-interest' on the side of a corporation that understands that its success is predicated on an equitable relationship to all groups affecting the firm's success. In many cases, especially in contexts of poor governance, vast income inequalities, or institutional voids, the need for BGs to engage with stakeholders is treated as more of a necessity or an unavoidable constraint than a deliberate engagement. In this context it is worth noting that in some jurisdictions dominated by BGs, most notably India and China, stakeholder engagement is nowadays no longer voluntary-which is a longstanding assumption underlying stakeholder engagement in the West. Afsharipour and Rana's (2014, p. 229) analysis suggests that efforts to develop a Chinese or Indian CSR model that "deviates from the voluntary CSR model of the West, is in part rooted in the desire of each government to address uneven economic development, widening income disparities, and increasing public dissent in their respective countries." Hence companies in these countries face mandatory requirements to engage and respect their stakeholders-which flies in the face of much of the assumptions of stakeholder theory, certainly in their normative interpretations (Donaldson and Preston 1995).

Linking the contributions of this Special Issue to the ongoing debate about an adequate theory of the firm reveals that any pursuit of this nature has to look at alternative ways to organize private business in a capitalist system. In particular the focus on CSR and how BGs relate (for better or for worse) to the public good suggests a much broader remit and role of business. While the CSR literature has opened up to look at other forms of business, such as hybrid businesses, SMEs, family-owned businesses or state-owned enterprises, the focus on BGs can enrich and inform this debate significantly.

\section{Conclusions and Directions for Future Research}

In conclusion we would argue that this Special Issue and its exploratory nature can provide the contemporary scholarly debate with some impulses. Firstly, we would argue that engaging with BGs as a specific actor in organizing CSR and the corporate role in society in general can contribute to a more refined understanding of the nature of the firm, its boundaries, and its implications for CSR. Secondly, this Special Issue can in some ways empower and lend a voice to CSR-related research in emerging economics. This is especially relevant to those parts of the globe out of which a flurry of CSR-related work is currently originating as well as where considerable graduate research is expected to be generated over the coming decades.

Finally, investigating the social role of BGs provides a unique perspective on the ambiguities of CSR and the ongoing necessity to find broader, system-level solutions to many of the criticisms contemporarily leveled against the corporate role in society.

\section{The Nature of the Firm}

Regarding the nature of the firm it is striking that, despite a surge of work on CSR and business ethics in the developing 
and emerging economies, the specific nature of dominant firms in those parts of the globe has received little attention. The tacit assumption in much of this body of country, regional, or comparative studies is to treat firms as a 'black box' - tacitly assuming that companies in, e.g., Korea, India, or China are basically similar and comparable to the publicly owned, shareholder governed firm that dominates much of the management literature. This pertains particularly to the influence of family ownership and state ownership of BGseven though the latter aspect did not feature prominently in this Special Issue. As Matten and Moon (2008) have argued, the shape and content of CSR are heavily dependent on the 'nature of the firm.' It is therefore indispensable to appreciate the specifics of the corporate form for a refined understanding of CSR in emerging economies where BGs are the dominant players.

A great example for the perils of ignoring the nature of the firm is the rather confused, misleading and ongoing debate in Western scholarly outlets around the Indian Companies Act 2013 (Gatti et al. 2018). Such criticism focuses on the issue of making CSR mandatory and around the question of whether this legislative approach assigns corporations a role that ideally governments should assume. The logic of the Companies Act though only becomes clear with an understanding the specific nature of the firm. In mandating $2 \%$ of net profits to be spent on CSR for the 6000 largest Indian companies, the intention of the Act clearly targets the existing capacities, skills, and governance mechanisms of companies to provide basic welfare provision (i.e., philanthropy or charity). Rather than just taxing companies, the idea is to avoid more resources flowing into a largely inefficient and often poorly governed public sector, but to use the existing governance infrastructure of BGs, as dominant actors in the Indian economy, to deliver additional social goods. The rationale of such an approach can only be understood, if one both appreciates the institutional voids and deficiencies of the public governance system in India, as well as the considerable capacity of private businesses to actually deliver those welfare state provisions. From a lens of corporate citizenship and the political nature of CSR such a role of corporations is just consistent. The controversy and the dismissal of the Indian approach is therefore largely based on ignorance-with regard to the specific capacities, roles, and governance structures of BGs in India.

\section{Geographical Context of Business Groups}

This Special Issue is quite focused on emerging economies, most notably India and Korea. In some ways this is unsurprising-given the high significance of BGs in these countries. Arguably, this also indicates institutional environments that make sufficient data available, as well as a fairly developed community of scholars-local or based elsewhere-with an interest in the role of businesses and CSR in these countries. As the paper by Cuervo-Cazurra points out, the developing or emerging economy context presents a specific context that has strong influence on the nature of CSR and wider pro-social activities of BGs. It further argues that the nature of CSR changes quite significantly with development, resulting in a shift in focus from social to economic and environmental aspects of CSR. This difference is already visible if we compare this Special Issue's papers from the Indian to those from the Korean context. Although not specifically focused on BGs but built largely based upon interviews with leaders of BGs in emerging markets, Gao et al.'s (2017) theoretical paper proposes that in emerging markets, a favorable reputation acts as a "meta-resource" that allows a firm to activate its conventional resources and overcome information-based voids. They further propose that in emerging markets, a favorable reputation can be a source of long-term survival; it enables firms to capitalize on new opportunities and buffers them against threats. The authors propose that the greater the extent and degree of institutional voids in an environment, the greater the upside of reputation's meta-resource effects will be. This framing is in line with the suggestion to look at BGs' CSR from a development perspective.

BGs, however, also exist in developed, Western economies. Many large and influential companies in Sweden, Italy, or France, but also several enterprises in economies dominated by the 'Anglo-Saxon' model of the firm, such as the USA, Canada, or Australia, are BGs. As such, their CSR approach has been understudied and the 'black box'-nature of these firms in those specific countries has been underexplored. For instance, there is quite a substantial body of work on the specific Scandinavian forms of CSR, based on an alleged 'Nordic model' (e.g., Gjølberg 2010; Strand and Freeman 2015). There is however scant appreciation that such a model is crucially dependent on a different understanding and practice of what a corporation is, how it relates to the political economy and to the implicit contract with the social democratic state. The absence of short termism, the focus on stakeholders beyond shareholders, or the focus on local communities in Scandinavian firms is not simply a cultural attribute of these countries. It is rather predicated on a different, historically grown model of what a firm should be-in purpose, intent, and execution-that informs a different approach to corporate contributions to the public good and, more contemporarily, CSR. An explicit appreciation of the nature of the firm would then lead to a better and more powerful explanation of CSR in those countries, as well as why and how it differs from other societal contexts. Overall, we suggest a context based theoretical approach to CSR of BGs with no convergence to a standard global model that focuses on the evolution of institutions within countries. 
An emerging and even less understood phenomenon are BGs formed through government-controlled investment companies and sovereign wealth funds. This form departs from the state-controlled BGs in China where control is established through the political party in power. In the case of Ministry of Finance Incorporated in Malaysia for example, the majority of chairmen are current or former politicians and bureaucrats although the operational management is largely entrusted to professionals. The Malaysian state has an ownership interest in 35 of the top 100 Malaysian companies, who between them account for $40 \%$ of total market capitalization, with a direct or an indirect interest in over 68,000 companies (Gomez et al. 2018). This means that the state retains the ability to intervene in the running of the company-if necessary through informal ties. In a similar vein, the primary sovereign wealth fund in Singapore, Temasek, has at least a $15 \%$ stake in 30 listed companies. An analysis of the composition of the boards of these 30 companies shows that while the majority of CEOs are professionals, two-thirds of the chairmen had state or political affiliations. Furthermore, $30 \%$ of their board members were in some way affiliated with Temasek. This also means that the state retains the ability to intervene in the running of the company-if necessary through informal ties. BGs in such geographical and political contexts-often paired with democratic deficits - may thus assume a rather ambiguous role with regard to social responsibility and their enhancement of the public good depending on the nature of the state.

\section{The Ambiguities of CSR in the Context of BGs}

Fundamentally, the phenomenon of CSR in BGs and their impact on-and contribution to- the public good is underexplored. As the papers in this Special Issue show, most BGs have a rather strong engagement in CSR through philanthropy and charity. This is a classic 'bolt-on' approach to CSR, where companies share and 'give back' part of their economic success, while at the same time paying less attention to the question of how far the generation of their success complies with such societal expectations as employee's rights or environmental impacts. The latter is a 'built-in' approach to forms of CSR which appears to be rather reluctantly embraced by BGs. As the papers on the darker features of BGs, such as blocking market access or tax avoidance, in this Special Issue illustrate a stronger focus on the specific nature of CSR in BGs could finally also inform a more normative research agenda.

A similar ambiguity surrounds the general role of BGs particularly in emerging economies. In the same vein as Pattnaik et al.'s argument in this Special Issue, with regard to the manipulation of product markets, we observe a similar role of BGs with regard to most notably capital markets in their specific jurisdictions. The internal capital market, whereby group affiliates access finance from each other, is an important characteristic of BGs. Existing studies have shown that continued dependence on internal capital market reduces the motivation of group affiliates to disseminate corporate information to market intermediaries such as stock analysts, restricting the development of external capital markets (Pattnaik et al. 2013). It is in this context that there is a greater need to shift the academic discourse to examine the ethical implications of firm behavior, instead of only the efficiency-enhancing role of firms in society.

Acknowledgements We would like to thank JBE Associate Editor Robert Philipps for helpful suggestions on earlier versions of this article. Manuscripts submitted to and published in the Special Issue have been at least double-blind reviewed. We would like to thank all reviewers for their thoughtful comments: Farzad Alvi, Kenneth Amaeshi, Bimal Arora, Preet Aulakh, Kee-Hong Bae, Ralph Barkemeyer, Sumon Bhaumik, Xuesong Geng, Sarah M. Jastram, Ayse Karaevli, Kiridaran Kanagaretnam, Hicheon Kim, Rebecca Chunghee Kim, Woojin Kim, Arno Kourula, Sareh Pouryousefi, Luc Renneboog, Judith SchrempfStirling, Laura J. Spence, Yishay Yafeh, B.Burcin Yurtoglu, and Alessandro Zattoni.

\section{Compliance with Ethical Standards}

Conflict of interest All three authors declare that they have no conflict of interest.

Ethical Approval This article does not contain any studies with human participants or animals performed by any of the authors.

\section{References}

Afsharipour, A., \& Rana, S. (2014). The emergence of new corporate social responsibility regimes in China and India. UC Davis Business Law Journal, 14, 175-230.

Agarwal, S. (2016). Corporate social responsibility vs corporate sustainability in India: A case study on Aditya Birla Group. International Journal for Innovative Research in Multidisciplinary Field, 2(6), 76-88.

Almeida, H., \& Wolfenzon, D. (2006). Should business groups be dismantled? The equilibrium costs of efficient internal capital markets. Journal of Financial Economics, 79, 99-144.

Ararat, M. (2005). Social responsibility in a state-dependent business system. In A. Habisch, J. Jonker, M. Wegner, \& R. Schmidpeter (Eds.), Corporate social responsibility across Europe. Berlin: Springer, 247-61.

Ararat, M., Black, B. S., \& Yurtoglu, B. B. (2014). Corporate governance, business groups, and market value: Time-series evidence from Turkey. Northwestern Law \& Econ Research Paper No. 13-19; ECGI-Finance Working Paper.

Ararat, M., Black, B. S., \& Yurtoglu, B. B. (2017). The effect of corporate governance on firm value and profitability: Time-series evidence from Turkey. Emerging Markets Review, 30, 113-132.

Baars, G., \& Spicer, A. (2017). The corporation: A critical, multidisciplinary handbook. Cambridge: Cambridge University Press.

Bae, K.-H., Kim, S.-B., \& Kim, W. (2012). Family control and expropriation at not-for-profit organizations: Evidence from Korean Private Universities. Corporate Governance: An International Review, 20(4), 388-404. 
Barley, S. R. (2007). Corporations, democracy, and the public good. Journal of Management Inquiry, 16(3), 201-215.

Barton, D., Horváth, D., \& Kipping, M. (Eds.). (2016). Re-imagining capitalism. Oxford York: Oxford University Press.

Baumol, W. J. (1990). Entrepreneurship: Productive, unproductive, and destructive. Journal of Political Economy, 98(5, Part 1), 893-921.

Bebchuk, L. A., \& Hamdani, A. (2018). The agency costs of controlling shareholders. Working Paper, Harvard Law School.

Belenzon, S., Berkovitz, T., \& Rios, L. A. (2013). Capital markets and firm organization: How financial development shapes European corporate groups. Management Science, 59, $1326-1343$

Berle, A. A., \& Means, G. C. (1932). The modern corporation and private property. New York: Transaction.

Bugra, A. (1994). State and business in modern Turkey: A comparative study. Albany, NY: SUNY Press.

Cankorel, T. (2015). Shareholder fiduciary duties: A review of Turkey's new "Group of Companies" regime in light of Delaware fiduciary duty law. Turkish Commercial Law Review, 1(1), 61.

Carney, M., Gedajlovic, E. R., Heugens, P. P., Van Essen, M., \& Van Oosterhout, J. H. (2011). Business group affiliation, performance, context, and strategy: A meta-analysis. Academy of Management Journal, 54, 437-460.

Carroll, A. B. (1991). The pyramid of corporate social responsibility: Toward the moral management of organizational stakeholders. Business Horizons, 34(4), 39-48.

Carroll, A. B. (1998). The four faces of corporate citizenship. Business and Society Review, 100(1), 1-7.

Child, J. (2002). The international crisis of confidence in corporations. Academy of Management Executive, 16(3), 145-149.

Cho, E. H., Chun, S. B., \& Choi, D. S. (2015). International diversification, corporate social responsibility, and corporate governance: Evidence from Korea. The Journal of Applied Business Research, 31(2), 743-764

Choi, B. B., Lee, D., \& Park, Y. (2013). Corporate social responsibility, corporate governance and earnings quality: Evidence from Korea, Corporate Governance. An International Review, 21(5), 447-467.

Claessens, S., Djankov, S., Fan, J. P. H., \& Lang, L. H. P. (2002a). Disentangling the incentive and entrenchment effects of large shareholdings. Journal of Finance, 57, 2741-2771.

Claessens, S., Fan, J. P. H., \& Lang, L. H. P. (2002b). The benefits and costs of group affiliation: Evidence from East Asia. CEPR Discussion Paper No. 3364.

Claessens, S., \& Kodres, M. L. E. (2014). The regulatory responses to the global financial crisis: Some uncomfortable questions (No. 14-46). International Monetary Fund.

Colpan, A. M. (2010). Business groups in Turkey. In A. M. Colpan, T. Hikino, \& J. Lincoln (Eds.), Oxford handbook of business groups (pp. 486-525). Oxford: Oxford University Press.

Colpan, A. M., \& Cuervo-Cazurra, A. (2018). Business groups as an organizational model. In J. Aldag (Ed.) Oxford research encyclopedia of business and management. Oxford University Press, forthcoming. https://doi.org/10.1093/acrefore/9780190224 851.013.97.

Colpan, A. M., \& Hikino, T. (2010). Foundations of business groups: Towards an integrated framework. In A. M. Colpan, T. Hikino, \& J. Lincoln (Eds.), Oxford handbook of business groups (pp. 15-66). Oxford: Oxford University Press.

Colpan, A. M., \& Hikino, T. (2018). Business groups in the west: Origins, evolution and resilience. Oxford: Oxford University Press.

Colpan, A. M., Hikino, T., \& Lincoln, J. R. (2010). The Oxford handbook of business groups. Oxford: Oxford University Press.

Crane, A., Matten, D., \& Moon, J. (2008). Corporations and citizenship. Cambridge: Cambridge University Press.
Dávila, C., \& Dávila, J. C. (2014). The evolution of a socially committed business group in Colombia, 1911-1985. Australian Economic History Review, 54(2), 164-182.

Djankov, S., La Porta, R., Lopez-de-Silanes, F., \& Shleifer, A. (2008). The law and economics of self-dealing. Journal of Financial Economics, 88, 430-465.

Donaldson, T., \& Preston, L. E. (1995). The stakeholder theory of the corporation: Concepts, evidence, and implications. Academy of Management Review, 20(1), 65-91.

Donaldson, T., \& Walsh, J. P. (2015). Toward a theory of business. Research in Organizational Behavior, 35, 181-207.

El Ghoul, S., Guedhami, O., \& Pittman, J. (2016). Cross-country evidence on the importance of Big Four auditors to equity pricing: The mediating role of legal institutions. Accounting, Organizations and Society, 54, 60-81.

Faccio, M., Masulis, R. W., \& McConnell, J. (2006). Political connections and corporate bailouts. Journal of Finance, 61, 2597-2635.

Fisman, R., \& Khanna, T. (2004). Facilitating development: The role of business groups. World Development, 32(4), 609-628.

Freeman, R. E. (2010). Strategic management. A stakeholder approach. New York: Cambridge University Press. (Reprint of the 1984 original.)

Gao, C., Zuzul, T., Jones, G., \& Khanna, T. (2017). Overcoming institutional voids: A reputation-based view of long-run survival. Strategic Management Journal, 38(11), 2147-2167.

Gatti, L., Vishwanath, B., Seele, P., \& Cottier, B. (2018). Are we moving beyond voluntary CSR? Exploring theoretical and managerial implications of mandatory CSR resulting from the New Indian Companies Act. Journal of Business Ethics, 1-12.

Ghemawat, P., \& Khanna, T. (1998). The nature of diversified business groups: A research design and two case studies. Journal of Industrial Economics, 46, 35-61.

Gjølberg, M. (2010). Varieties of corporate social responsibility (CSR): CSR meets the "Nordic Model". Regulation \& Governance, 4(2), 203-229.

Gomez, E. T., Padmanabhan, T., Kamaruddin, N., Bhalla, S., \& Fisal, F. (2018). Minister of finance incorporated: Ownership and control of corporate Malaysia. Singapore: Palgrave Macmillan/ Springer Nature.

Granovetter, M. (2005). Business groups and social organization. In N. J. Smelser \& R. Swedburg (Eds.), The handbook of economic sociology (2nd ed., pp. 429-450). Princeton, NJ: Princeton University Press.

Guereña, A. (2013). The soy mirage: The limits of corporate social responsibility - the case of the company Desarrollo Agrícola del Paraguay. Oxfam Research Reports, ISBN: 978-1-78077-398-8.

Guillen, M. (2000). Business groups in emerging economies: A resource-based view. Academy of Management Journal, 43(3), 362-380.

Hawley, J. P., \& Williams, A. T. (2007). Universal owners: Challenges and opportunities. Corporate Governance: An International Review, 15(3), 415-420.

Holmen, M., \& Högfeldt, P. (2009). Pyramidal discounts: Tunneling or overinvestment. International Review of Finance, 9(1-2), $133-175$.

Holmes, R. M. Jr., Hoskisson, R. E., Kim, H., Wan, W. P., \& Holcomb, T. R. (2016). International strategy and business groups: A review and future research agenda. Journal of World Business, $53,134-153$

Hoque, N., Uddin, M. R., Ibrahim, M., \& Mamun, A. (2014). Corporate social responsibilities (CSR) as a means of materializing corporate vision: A Volvo Group approach. Asian Social Science, 10(11), 258-268.

Hoskisson, R. E., Johnson, R. A., Tihanyi, L., \& White, R. (2005). Diversified business groups and corporate refocusing in emerging economies. Journal of Management, 31, 941-965. 
Jamali, D. (Ed.). (2016). Comparative perspectives on global corporate social responsibility. Hershey, PA: IGI Global.

Jamali, D., \& Karam, C. (2018). Corporate social responsibility in developing countries as an emerging field of study. International Journal of Management Reviews, 20(1), 32-61.

Jones, G. (2015). Business groups exist in developed markets also: Britain Since 1850. Harvard Business School Working Paper, No. 16-066, November 2015.

Kantabutra, S., \& Avery, G. C. (2011). Sustainable leadership at Siam Cement Group. Journal of Business Strategy, 32(4), 32-41.

Khanna, N., \& Rivkin, J. (2001). Estimating the performance effects of business groups in emerging markets. Strategic Management Journal, 22, 45.

Khanna, T. (2000). Business groups and social welfare in emerging markets: Existing evidence and unanswered questions. European Economic Review, 44, 748-761.

Khanna, T., \& Palepu, K. (1997). Why focused strategies may be wrong for emerging markets. Harvard Business Review, 7(4), 41-51.

Khanna, T., \& Palepu, K. (1999). The right way to restructure conglomerates in emerging markets. Harvard Business Review, 77, $125-134$.

Khanna, T., \& Palepu, K. (2000). The future of business groups in emerging markets: Long run evidence from Chile. Academy of Management Journal, 43(3), 268-285.

Khanna, T., \& Rivkin, J. W. (2006). Interorganizational ties and business group boundaries: Evidence from an emerging economy. Organization Science, 17, 333-352.

Khanna, T., \& Yafeh, Y. (2007). Business groups in emerging markets: Paragons or parasites? Journal of Economic Literature, 45, 331-372.

Kim, B., Pae, J., \& Yoo, C.-Y. (2017). Business groups and tunneling: Evidence from corporate charitable contributions by Korean companies. Journal of Business Ethics, 1-24.

Kim, H. (2010). Business groups in South Korea. In A. M. Colpan, T. Hikino, \& J. Lincoln (Eds.), Oxford handbook of business groups (pp. 157-179). Oxford: Oxford University Press.

Kock, C., \& Guillen, M. (2001). Strategy and structure in developing countries: Business groups as an evolutionary response to opportunities for unrelated diversification. Industrial and Corporate Change, 10(1), 77-113.

Krueger, A. O. (1974). The political economy of the rent-seeking society. The American Economic Review, 64(3), 291-303.

La Porta, R., Lopez-de-Silanes, F., \& Shleifer, A. (1999). Corporate ownership around the world. Journal of Finance, 54(2), 471-517.

Leff, N. H. (1978). Industrial organization and entrepreneurship in the developing countries: The economic groups. Economic Development and Cultural Change, 26(4), 661-675.

Marano, V., Tashman, P., \& Kostova, T. (2016). Escaping the iron cage: Liabilities of origin and CSR reporting of emerging market multinational enterprises. Journal of International Business Studies, 48(3), 386-408.

Masulis, R. W., Pham, P. K., \& Zein, J. (2011). Family business groups around the world: Financing advantages, control motivations, and organizational choices. Review of Financial Studies, 24, $3556-3600$

Masulis, R. W., \& Reza, S. W. (2014). Agency problems of corporate philanthropy. The Review of Financial Studies, 28(2), 592-636.

Matten, D., \& Crane, A. (2005). Corporate citizenship: Toward an extended theoretical conceptualization. Academy of Management Review, 30(1), 166-179.

Matten, D., \& Moon, J. (2008). 'Implicit' and 'explicit' CSR: A conceptual framework for a comparative understanding of corporate social responsibility. Academy of Management Review, 33(2), 404-424.
McWilliams, A., \& Siegel, D. (2001). Corporate social responsibility: A theory of the firm perspective. Academy of Management Review, 26(1), 117-127.

Melis, A. (2005). Corporate governance failures: To what extent is Parmalat a particularly Italian case? Corporate Governance: An International Review, 13(4), 478-488.

Mena, S., Rintamäki, J., Fleming, P., \& Spicer, A. (2016). On the forgetting of corporate irresponsibility. Academy of Management Review, 41(4), 720-738.

Min, B. S. (2017). Organizational assimilation to changed institutional logic: Does business group matter? Working paper presented at Kyoto University Graduate School of Economics Seminar, November 16, 2017.

Montecchia, A., \& Di Carlo, E. (2015). Corporate social disclosure under isomorphic pressures: Evidence from business groups. International Journal of Business Governance and Ethics, 10(2), 137-164.

Morck, R. (2010). The riddle of great pyramids. In A. M. Colpan, T. Hikino, \& J. Lincoln (Eds.), Oxford handbook of business groups (pp. 602-628). Oxford: Oxford University Press.

Morck, R., Wolfenzon, D., \& Yeung, B. (2005). Corporate governance, economic entrenchment, and growth. Journal of Economic Literature, 43, 655-720.

Morck, R., \& Yeung, B. (2004). Family control and the rent seeking society. Entrepreneurship Theory and Practice, 28(4), 391-409.

O'Shaughnessy, K. C., Gedajlovic, E., \& Reinmoeller, P. (2007). The influence of firm, industry and network on the corporate social performance of Japanese firms. Asia Pacific Journal of Management, 24(3), 283-303.

Oba, V. C. (2011). Impact of corporate social responsibility on the market value of quoted conglomerates in Nigeria. ICAN Journal of Accounting and Finance, 1(3), 64-70.

Ocasio, W. (1997). Towards an attention-based view of the firm. Strategic Management Journal, 18, 187-206.

Oh, W. Y., Chang, Y. K., \& Martynov, A. (2011). The effect of ownership structure on corporate social responsibility: Empirical evidence from Korea. Journal of Business Ethics, 104(2), 283-297.

Pagano, M., \& Volpin, P. F. (2005). Managers, workers, and corporate control. Journal of Finance, 60(2), 841-868.

Pattnaik, C., Chang, J. J., \& Shin, H. H. (2013). Business groups and corporate transparency in emerging markets: Empirical evidence from India. Asia Pacific Journal of Management, 30(4), 987-1004.

Pegg, S. (2012). Social responsibility and resource extraction: Are Chinese oil companies different? Resources Policy, 37, 160-167.

Puchniak, D. W., \& Kim, K. S. (2017). A taxonomy. Independent Directors in Asia: A Historical, Contextual and Comparative Approach, 15(355), 89.

Reich-Graefe, R. (2005). Changing paradigms: The liability of corporate groups in Germany. Connecticut Law Review, 37, 785-817.

Rossouw, G. (2005). Business Ethics and Corporate Governance in Africa. Business \& Society, 44(1), 94-106.

Scherer, A. G., \& Palazzo, G. (2007). Toward a political conception of corporate responsibility - business and society seen from a Habermasian perspective. Academy of Management Review, 32(4), 1096-1120.

Scherer, A. G., \& Palazzo, G. (2011). The new political role of business in a globalized world: A review of a new perspective on CSR and its implications for the firm, governance, and democracy. Journal of Management Studies, 48(4), 899-931.

Scherer, A. G., Rasche, A., Palazzo, G., \& Spicer, A. (2016). Managing for political corporate social responsibility: New challenges and directions for PCSR 2.0. Journal of Management Studies, 53(3), 273-298.

Schneider, B. R. (2010). Business groups and the state: The politics of expansion, restructuring and collapse. In A. M. Colpan, T. 
Hikino, \& J. Lincoln (Eds.), Oxford handbook of business groups (pp. 650-669). Oxford: Oxford University Press.

Schwartz, M. S., \& Carroll, A. B. (2003). Corporate social responsibility: A three domain approach. Business Ethics Quarterly, 13(4), 503-530.

Shah, S. (2014). Corporate social responsibility: A way of life at the Tata Group. Journal of Human Values, 20(1), 59-74.

Sheikh, A. (2017). Corporate social responsibility: Bajaj Group, Journal of Industrial Relationship. Corporate Governance \& Management Explorer, 1(1), 12-20.

Shiu, Y. M., \& Yang, S. L. (2017). Does engagement in corporate social responsibility provide strategic insurance-like effects? Strategic Management Journal, 38(2), 455-470.

Strand, R., \& Freeman, R. E. (2015). Scandinavian cooperative advantage: The theory and practice of stakeholder engagement in Scandinavia. Journal of Business Ethics, 127(1), 65-85.

Talisayon, S. D. (2010). Corporate social responsibility and emergent models in management of stakeholder capital in Philippine conglomerates. Journal of Asian Business, 4(1\&2), 67-86.

Tata, R. N., \& Matten, D. (2016). Corporate community involvement in the 21 st century. In D. Barton, D. Horvath, \& M. Kipping (Eds.), Re-imagining capitalism (pp. 68-83). Oxford: Oxford University Press.

Villalonga, B., \& Amit, R. H. (2009). How are U.S. family firms controlled? The Review of Financial Studies, 22(8), 3047-3091.
Visser, W. (2008). CSR in developing countries. In A. Crane, A. McWilliams, D. Matten, J. Moon, \& D. Siegel (Eds.), The Oxford handbook of CSR (pp. 473-499). Oxford: Oxford University Press.

Weston, G. G. (2016). Family firms and 'patient' capital: Thinking in decades, not in quarters. In D. Barton, D. Horvath, \& M. Kipping (Eds.), Re-imagining capitalism (pp. 42-54). Oxford: Oxford University Press.

Williamson, O. E. (1991). Comparative economic organization: The analysis of discrete structural alternatives. Administrative Science Quarterly, 36, 269-296.

Witt, M. A., \& Redding, G. (2013). Asian business systems: Institutional comparison, clusters and implications for varieties of capitalism and business systems theory. Socio-Economic Review, 11(2), 265-300.

Yiu, D., Bruton, G. D., \& Lu, Y. (2005). Understanding business group performance in an emerging economy: Acquiring resources and capabilities in order to prosper. Journal of Management Studies, 42, 183-206.

Yiu, D. W. (2011). Multinational advantages of Chinese business groups: A theoretical exploration. Management and Organization Review, 7, 249-277.

Yiu, D. W., Lu, Y., Bruton, G. D., \& Hoskisson, R. E. (2007). Business groups: An integrated model to focus future research. Journal of Management Studies, 44, 1551-1579. 